\title{
Oestrogenic activity in drinking waters from a rural area in the Waterberg District, Limpopo Province, South Africa
}

\author{
NH Aneck-Hahn ${ }^{1 *}$, MS Bornman ${ }^{1}$ and C de Jager ${ }^{1,2}$ \\ ${ }^{1}$ Andrology, Department of Urology, University of Pretoria, Pretoria, South Africa \\ ${ }^{2}$ Environmental Health, School of Health Systems and Public Health, University of Pretoria, Pretoria, South Africa
}

\begin{abstract}
In South Africa, limited data are available regarding possible oestrogenic activity in the aquatic systems and especially drinking water. Water in the rural areas is often contaminated with a complex mixture of toxic compounds originating from nearby industries, agriculture and households. In these rural areas the only access to drinking water is boreholes, natural springs and rivers. Thus human exposure to environmental contaminants in drinking water is potentially high. Two rural communities near Mokopane in the Waterberg district of the Limpopo Province were selected in order to screen for oestrogenic activity in drinking water sources in a rural area. Eleven $1 \ell$ water samples (Molekane $n=4$; Sekuruwe $n=7$ ), were collected in prepared glass bottles and extracted on a SPE C18 cartridge and reconstituted into ethanol. The recombinant yeast oestrogen screen was used to determine the oestrogenic activity in the extracts. 17/-estradiol (E2) was used as a positive control and the results were expressed as estradiol equivalents (EEq). The EEq of the water from both the communities ranged between $0.63-2.48$ $\mathrm{x} 10^{-9} \mathrm{~g} / \ell$. These concentrations are similar to other studies conducted in Korean river waters in rural and city areas and Flemish surface waters. The recombinant yeast screen confirmed oestrogenic activity in the drinking water samples; further investigation is necessary to determine the source of the contamination and association with impaired growth.
\end{abstract}

Keywords: recombinant yeast screen, oestrogenic activity, water, rural, Limpopo, South Africa

\section{Introduction}

Worldwide, there are a number of reports on the presence of a variety of environmental chemicals with oestrogenic activity in aquatic systems. A number of industrial, agricultural and household chemicals released into the environment are believed to disrupt normal endocrine function in humans and animals (Colborn et al., 1993, Toppari et al., 1996, Jobling and Tyler, 2006). These endocrine disrupting chemicals (EDCs) include a wide range of molecules such as organochlorine pesticides, phthalates, alkylphenols, natural hormones and pharmaceuticals (Safe and Gaido, 1998). Endocrine disruption has been associated with wildlife with observations documenting oestrogenic, androgenic and anti-thyroid actions in fish found in sewage and paper mill effluents; exposure of alligators to agricultural chemicals; and exposure of birds, fish and mammals to complex mixtures of chemicals in North America and Europe (Guillette, 2006). In South Africa the first histological evidence of intersex in feral sharptooth catfish from oestrogen-polluted water was reported by Barnhoorn et al. (2004). These effects in response to ecologically relevant exposure levels have been observed in a number of vertebrate species (Guillette, 2006), for example infertility and behavioural changes in polar bears, beluga whales and laboratory animals (Colborn et al., 1993; Kamrin, 1996; Kilian et al.,2007).

Human health impacts that have been attributed to EDC exposure include, abnormalities in male reproductive health (Aneck-Hahn et al., 2007; De Jager et al., 1999; De Jager et al.,

\footnotetext{
* To whom all correspondence should be addressed.

疋 +2712 354 1676; fax: +2712 354 2500; e-mail: haneckha@medic.up.ac.za

Received 27 February 2007; accepted in revised form 4 February 2009.
}

2001; Kamrin, 1996; Kilian et al., 2007; Phillips and Foster, 2008; Toppari et al., 1996); female reproductive health (Kirkhorn and Schenker, 2002; Sharpe and Skakkebaek, 1993); increased incidence of reproductive cancers (Sharpe and Skakkabaek, 1993); immunological effects (WHO, 2002); neurodevelopmental effects (Eskenazi et al., 2006) and thyroid disease (Phillips and Foster, 2008; WHO, 2002). More recently diabetes, obesity and anogenital distance have been identified as new biological endpoints (Phillips and Foster, 2008).

Currently only limited data are available on the levels of oestrogenic contamination in aquatic systems in South Africa. A pilot study to determine the presence of specific chemicals (p-nonylphenol (p-NP), polychlorinated biphenyls (PCBs) and organochlorine pesticides) known to have oestrogenic activity was performed on water samples from particular South African rivers and dams during the summer of 1998/99. The results indicated that there was oestrogenic contamination in a number of areas. A study done in November 2001 in the Rietvlei Nature Reserve reported oestrogenic activity between 0.31 and 2.1 $\mathrm{ng} / \ell$ in various surface and groundwater sites (Aneck-Hahn et al., 2008). A more comprehensive study done in the Reserve over a 2-year period indicated that the oestrogenic activity had increased with cytotoxicity (69\%) being reported in the YES assay and oestrogenic activity between 0.16 and $1.92 \mathrm{ng} / \ell$. The more sensitive ER-Calux assay confirmed the oestrogenic activity between 0.32 and $16.0 \mathrm{ng} / \ell$ (Bornman et al., 2007). This is a disturbing finding, in the light of the limited water resources in South Africa, as many humans and animals are dependent on these sources for their drinking water (De Jager et al., 2000; Bornman et al., 2007).

In South Africa the environments in rural and urbanised areas are often contaminated with a complex mixture of toxic compounds originating from industries, agriculture and private households (Aneck-Hahn, 2003). Many of these pollutants end 
up in surface waters, such as dams, rivers and eventually the ocean. Toxic contaminants may disturb the biological condition of aquatic ecosystems and be harmful for humans exposed through food or drinking water. In the rural areas the main sources of the communities' water for drinking and household purposes are local boreholes, natural springs and rivers.

Most chemical analytical methods are expensive and are not sufficient to identify all the environmental chemicals and to predict a combination of toxicity and bioavailability. A more appropriate strategy is to screen samples, using short-term, relatively inexpensive bioassays for indications of toxic effects and then to prioritise them for chemical analyses or more intensive studies (Aneck-Hahn, 2003). Many studies have focused on compounds that are oestrogen-receptor agonists including organochlorine pesticides, phthalates, alkylphenols, some natural hormones and some pharmaceuticals (Safe and Gaido, 1998). A number of assays have been developed to detect oestrogenic activity of chemicals, the Estrogen Screen (E-screen) (Soto et al., 1995), the Yeast Oestrogen Screen (YES-screen) (Routledge and Sumpter, 1996), the Estrogen Receptor mediated chemical activated luciferase gene expression (ER-Calux) (Legler et al., 1999) and the MCF-7-p-Vit-tk-Luc-Neo (MVLN) transgenic human cell line assay (Pons et al., 1990). These assays are also useful for detecting oestrogenic activity of complex environmental matrices such as effluents of wastewater treatment plants, or other industries or of surface waters (Desbrow et al., 1998; Witters et al., 2001; Van Den Belt et al., 2004). In vitro assays have advantages in terms of rapidity and low cost, saving on the use of animals (Phillips and Harrison, 1999).

The present study was an extension of a project initiated by the Department of Food and Hospitality Management of the Tshwane University of Technology (formerly Technikon Pretoria) on the nutritional status and dietary intake of children to determine whether poor diets increased the prevalence of stunting. The 2 rural villages Molekane and Sekuruwe in the Limpopo Province (formerly Northern Province) were selected because the people in these communities are poor, the unemployment rate is high and the lack of services and infrastructure could have an impact on chronic malnutrition among young children. The stunting rates among children in the Limpopo Province rural areas have been calculated to be $34 \%$ (Theron, 2000). The results of the study indicated that the nutritional diet, however, was not the cause of the stunted growth. This finding led to the hypothesis that the health status of the children was related to rapid urbanisation and informal settlements on the outskirts of cities where there is a risk of exposure to chemical contaminants that may impair growth. This study was conducted to determine whether the drinking-water sources in these areas contain oestrogenic contaminants.

\section{Materials and methods}

\section{Study area}

The Limpopo Province covers approximately one tenth of the total surface area of South Africa (Fig. 1). It comprises an area of $116824 \mathrm{~km}^{2}$, only $14 \%$ of which is arable land (Meintjes et al., 1995). Molekane is a rural community in the Waterberg district of the Limpopo Province. It is located $27 \mathrm{~km}$ north of Mokopane (Potgietersrus) and has approximately 800 households. Sekuruwe also situated in the Waterberg district, is $32 \mathrm{~km}$ north of Mokopane, $10 \mathrm{~km}$ from Molekane and has approximately 500 households. These two rural villages were selected because of the increasing prevalence of stunted growth in the children (Theron, 2000; Theron et al., 2007).

These 2 communities depend mostly on groundwater. Piped water is only available to $17 \%$ of the population, whereas $40 \%$ of the population rely on public taps and at least $11 \%$ of the population rely on dams, rivers, streams and springs for their water supply (Theron, 2000). There is no running water in the houses but those living nearby fetch it from the main line at communal taps or borehole pumps, using any available container, from plastic buckets to metal oil drums, and carry it back home. A few people own their own boreholes, from which they sell water to the community when the public water sources dry up. The most common toilet available is a pit latrine (Theron, 2000). There are no municipal waste-removal containers for refuse collection and household refuse is dumped alongside the road, burned or buried.

A peri-urban region near Pretoria had been selected as a control site for this study. Unfortunately this area could not be used as a control site as the levels of oestrogenic activity in the area were similar to those obtained in this study (Aneck-Hahn et al., 2008).

\section{Sample collection}

In November 2001 the University of Pretoria project team collected the water samples from the 2 communities, Molekane $(n=4)$ and Sekuruwe $(n=7)$, on the same day in a once-off

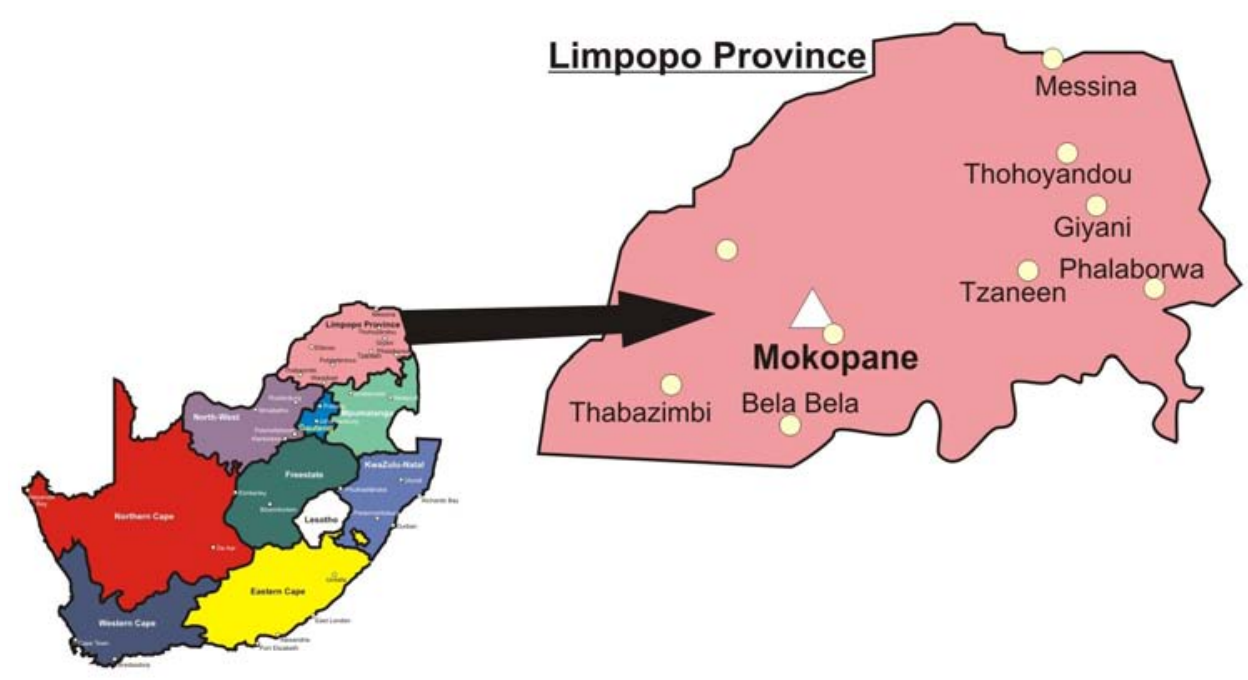

Figure 1

The two rural communities are situated in the Waterberg, Limpopo Province, north of Mokopane (Potgietersrus).

$\triangle$ : indicates the study area, where Molekane and Sekuruwe are situated 


\begin{tabular}{|c|c|c|}
\hline \multicolumn{3}{|c|}{$\begin{array}{c}\text { TABLE I } \\
\text { A description of the source and estrogenic activity of the water } \\
\text { samples expressed as estradiol equivalents (EEq) }(\mathrm{g} / \ell)\end{array}$} \\
\hline Sample site & Description of water source & EEq $(g / \ell)^{*}$ \\
\hline \multicolumn{3}{|l|}{ Molekane } \\
\hline Mol 1 & Mine water from tap (soccer field/shop) & $0.68 \times 10^{-9}$ \\
\hline Mol 2 & Borehole into plastic drum (personal borehole) & $1.82 \times 10^{-9}$ \\
\hline Mol 3 & Borehole water (personal borehole) & $1.30 \times 10^{-9}$ \\
\hline Mol 4 & Spring (and runoff from rain water) & $2.29 \times 10^{-9}$ \\
\hline \multicolumn{3}{|l|}{ Sekuruwe } \\
\hline Sek 1 & Tank (large plastic tank) & $<\mathrm{dl}$ \\
\hline Sek 2 & Borehole (personal borehole) & $2.15 \times 10^{-9}$ \\
\hline Sek 3 & Spring I (South side of town, main) & $2.48 \times 10^{-9}$ \\
\hline Sek 4 & Spring II (North side of town) & $0.63 \times 10^{-9}$ \\
\hline Sek 5 & Plastic drum & $1.90 \times 10^{-9}$ \\
\hline Sek 6 & Disei shop (water pump) & $0.83 \times 10^{-9}$ \\
\hline Sek 8 & Spring (West) & $<\mathrm{dl}$ \\
\hline
\end{tabular}

sampling exercise. Samples of surface water and groundwater pumped from boreholes were collected with a stainless steel cup and placed into $1 \ell$ glass Schott Suprax bottles (Cat. No. 21802 54 56) that had been pre-washed with ethanol (Cat. No. 27,0741, Sigma-Aldrich) and covered with tin foil. The samples were placed on ice and taken back to the laboratory on the same day and kept at $4{ }^{\circ} \mathrm{C}$ until extracted. There was no contamination or contact with the plastic lid of the bottles.

These samples were representative of the water sources available for consumption by the residents in the communities, their livestock and for other domestic use (Table I). Molekane 1 (Mol 1) was tap water supplied to the local soccer club from the nearby platinum mine. This water was also collected in and stored in plastic drums by the local community residents. Molekane 2 ( $\mathrm{Mol} 2$ ) was water collected from a personal household borehole, which is subsequently stored in a plastic drum. Molekane 3 ( $\mathrm{Mol} 3$ ) was also collected from a personal household borehole, but in a different area of the community. Molekane 4 ( $\mathrm{Mol} 4$ ) was a spring in the dry riverbed at the entrance to the community. This spring is used by both humans and animals as a water source for drinking and other domestic needs.

Sekuruwe 1 (Sek 1) was water from the nearby town, Mokopane, which was delivered by truck and pumped into and stored in a large plastic tank. Sekuruwe 2 (Sek 2) was collected from a household that had a personal borehole. There are 3 natural springs (Sek 3, 4 and 8) situated on the outskirts of the village. These springs are used by the residents of Sekuruwe and animals as a water source for drinking and other domestic needs. Specifically, Sek 8 is a spring that is situated to the west of the community across the tarred road with no houses or animal pens in close proximity. Water is collected from this spring in cans or drums and transported on a donkey cart to the community. Sekuruwe 5 (Sek 5) was water from a plastic drum that was standing outside a house; this water had been collected from the public borehole supplying the village. There was a public water pump situated in front of the local general store (Sek 6; Disei Shop) at the entrance to the informal settlement. This site was selected as it served as one of the major community watercollection points.

\section{Sample preparation}

\section{Water extraction procedure}

All glassware for sample storage, filtration and extraction of water samples was washed in chromic acid and rinsed once in methanol (Cat No. 34860, Riedel-de Haën) and twice in ethanol (Cat.No. 27,0741, Sigma-Aldrich). For extraction and enrichment of potential oestrogen-like compounds a solid phase extraction (SPE) was performed. A volume of $1 \ell$ was passed in 2 subsequent steps, through a glass wool filter (Cat. No. 000904, Macherey-Nagel), through a $0.45 \mu \mathrm{m}, 47 \mathrm{~mm}$ sterile filter (Cat. No. E04WG047S1, Osmonics, MicronSep) to remove particulates. The samples were extracted onto a preconditioned Chromabond C18 ec, SPE cartridge (Cat. No. 730 014, Macherey-Nagel), at a flow rate of $10 \mathrm{ml} / \mathrm{min}$ (Routledge et al., 1998). Control water (Renalcare ${ }^{\circledR}$ water prior to autoclaving (Aneck-Hahn et al., 2005)) was included to assess possible oestrogenic contamination from the SPE cartridge. The samples were then eluted from the cartridge with $3.5 \mathrm{~m} \ell$ methanol into sterile glass tubes (Cat No. 13099, Pierce, amber reacti-vials $\left.{ }^{\mathrm{TM}}, 5 \mathrm{m \ell}\right)$. The methanol was then evaporated under a gentle nitrogen stream (Beresford, 1999) using a Pierce, Reacti-Vap and a Reacti-Therm heating and stirring module. The sample residue was reconstituted with $1 \mathrm{~m} \ell$ ethanol and placed into sterile amber glass bottles (Cat. No.154515, Chromatography research supplies, $4 \mathrm{~m} \ell$ ), and stored at $-20^{\circ} \mathrm{C}$ prior to analysis.

\section{Recombinant yeast screen bioassay (RCBA)}

The Recombinant Yeast Screen Bioassay (RCBA) (including details of medium components) previously described by Routledge and Sumpter (1996), was used to test water for oestrogenic activity. In this system, yeast cells transfected with the human oestrogen receptor- $\alpha(E R-\alpha)$ gene, together with expression plasmids, containing oestrogen responsive elements and the lac- $Z$ reporter gene encoding the enzyme $\beta$-galactosidase, were incubated in a medium containing $17 \beta$-estradiol and the chromogenic substrate, chlorophenol red- $\beta$-d-galactopyranoside (CPRG). Active ligands, which bind to the receptor, induce $\beta$-galactosidase ( $\beta$-gal) expression and these cause the CPRG 
(yellow) to change into a red product that can be measured by absorbance.

The assay was carried out by the Andrology Laboratory at the University of Pretoria according to the standard assay procedure found in Routledge and Sumpter (1996) with modifications to the method described in Aneck-Hahn et al. (2005). In this assay $17 \beta$-estradiol (E2) was used as the calibration standard. The E2 standard curve was fitted ( sigmoidal function, variable slope) using Graphpad Prism (version 2.01), which calculated the minimum, maximum, slope, $\mathrm{EC}_{50}$ value and $95 \%$ confidence limits The oestrogenic activity was reported as the $50 \%\left(\mathrm{EC}_{50}\right)$ effect concentration using non-linear regression with a sigmoid curve fitting. The detection limit of each test plate (ranging between 0.6 and $2.7 \mathrm{ng} / \ell$ ) was calculated as absorbance elicited by the solvent control (blank) plus three times the standard deviation.

The dose-response curves for the extracted samples and the E2 (standard) curves were used to calculate the estradiol equivalent (EEq) values of the samples. Based on the dose-response curves for E2 and the test sample, the EE of each sample was calculated using the $\mathrm{EC}_{50}$ value (absorbance) of the sample. The concentration was then adjusted using the appropriate dilution factor.

\section{Results}

No oestrogenic activity was measured in the extraction control samples, thus contamination of the cartridges during the extraction process can be excluded. Yeast growth was checked at an absorbance of $620 \mathrm{~nm}$. Compared to the reference, none of the samples showed a decrease in cell density, therefore no cytotoxicity was present. The sample was considered positive for oestrogenic activity when three or more consecutive observations were above the detection limit of the assay. The oestrogenic activity (EEqs) of the samples is based on the $\mathrm{EC}_{50}$ value of the dose response curves obtained for 17ß-estradiol (E2) and the test sample.

\section{Molekane}

All the samples from Molekane had oestrogenic activity. Surface water from the mine tap, Mol 1 had the lowest oestrogenic activity $\left(0.68 \times 10^{-9} \mathrm{~g} / \ell \mathrm{EEq}\right)$ while the samples from the groundwater sources were all above $1 \mathrm{ng} / \ell$ EEq. The spring in the dry river bed, Mol $4\left(2.29 \times 10^{-9} \mathrm{~g} / \ell \mathrm{EEq}\right)$, had the highest oestrogenic activity (Table I).

\section{Sekuruwe}

Two of the samples (Sek 1; Sek 8) showed no oestrogenic activity as the $\mathrm{EC}_{50}$ absorbance for both samples was below the calculated detection limit of the assay, even before the dilution factor was considered. The rest of the samples had EEqs ranging between $0.63 \times 10^{-9}$ and $2.48 \times 10^{-9} \mathrm{~g} / \ell$ (Table I). The main spring to the south of the community (Sek 3) had the highest EEq $\left(2.48 \times 10^{-9} \mathrm{~g} / \ell\right)$ and the borehole (Sek 2) had the lowest EEqs $\left(0.83 \times 10^{-9} \mathrm{~g} / \ell\right)$. Water that had been collected from a public borehole pump in a plastic drum (Sek 5) also had an EEq of $1.90 \times 10^{-9} \mathrm{~g} / \ell$, while a sample from a personal borehole (Sek 2) situated in the garden and close to the house had an EEq of $2.15 \times 10^{-9} \mathrm{~g} / \ell$

\section{Discussion}

This once-off sampling study indicated that there was oestrogenic activity in all except 2 samples (Sek 1 and Sek 8). The reason for this could be that Sek 1 was treated water suitable for drinking from the nearby town, Mokopane. While Sek 8 was groundwater from a spring situated a distance away from the community, where water is collected in containers (metal and plastic) and taken back to the community on a donkey cart. No animals graze in the area and there is no other agricultural activity in the vicinity of the spring, limiting possible oestrogenic contamination.

The Molekane community lies adjacent to the platinum mine which has a slimes dam and the water is used to irrigate a nearby soccer field, but is also used by the community for drinking purposes. The pollution from the mine may be the source of the oestrogenic activity (EEq: $0.68 \times 10^{-9} \mathrm{~g} / \ell$ ) found in this sample (Mol 1), the low activity could be due to an anti-oestrogenic response. Metals are capable of binding to the ligand-binding domain (LBD) of the oestrogen receptor alpha (ER $\alpha)$ and then block the binding of 17ß-estradiol to this domain (Darbre, 2006). When attached to estradiol, metal ions (palladium and platinum) have been found to increase the relative binding affinity of ligand to receptors of MCF-7 cells (Darbre, 2006; Jackson et al., 2001). Metallo-oestrogens may also give rise to oestrogen-agonistic responses in cells (Darbre, 2006).

Of concern are the EEq-values of the remainder of the Molekane and Sekuruwe samples which ranged between $0.68 \times 10^{-9}$ and $2.29 \times 10^{-9} \mathrm{~g} / \ell$ and $0.63 \times 10^{-9}$ to $2.48 \times 10^{-9} \mathrm{~g} / \ell$ respectively. These are not surface water samples but groundwater samples indicating a high level of oestrogenic pollution of the groundwater system in the area in and bordering the communities. These equivalents were slightly lower than those found in a study determining oestrogenic activity (EEq: $10^{-9}-10^{-8} \mathrm{M}$ ) in river water samples from different provinces in South Africa, using a reporter gene assay (ER-Calux) (De Jager et al., 2002). It is to be expected as the YES assay is not as sensitive as the ER Calux which contains both ER $\alpha$ and ERß (Bornman et al., 2007; Leusch, 2008). However, the oestrogenic activity was in the same range ( 0.31 to $2.1 \mathrm{ng} / \ell)$ as those in the Rietvlei Nature Reserve sampled at the same time of the year using the YES assay (Aneck-Hahn et al., 2008) and other South African studies (Table 2). The other 3 springs (Mol 4, Sek 3 and 4) are all close to the informal settlements, suggesting that the source of oestrogenic contamination could be from the settlements themselves. The oestrogenic activity in the study also corresponds with a number of international studies summarised in Table 2.

EDCs are used in certain polycarbonate and the epoxy resin linings of food and beverage containers (Palanza et al., 2008), Krishnan et al. (1993) found that Bisphenol-A had leached from plastic flasks during autoclaving and Aneck-Hahn et al. (2005) found that sterile bottled water after autoclaving also exhibited oestrogenic activity. In rural communities water is often stored in any available container. Plastic containers such as the one used in Mol 2 and old oil drums could be possible sources of oestrogenic contamination. There is no municipal waste- removal service available, refuse is dumped, burned or buried. Basic services are lacking and the most common toilet available is a pit latrine. It is known that the presence of oestrogenic compounds in sewage represents one of the best examples of linkage between effects and exposure to EDCs (Damstra et al., 2002; Sarmah et al., 2006). Leachates from municipal solid waste landfills can also severely contaminate groundwater and surface waters with EDCs; this includes compounds from plastics like Bisphenol A, nonylphenol and other products (Zhang et al., 2009). Therefore there is a likelihood that the source of the oestrogenic activity in the ground- 


\begin{tabular}{|l|l|l|l|l|}
\hline \multicolumn{5}{|}{ Literature data on oestrogen levels in different water sources } \\
\hline Country & Water source & Oestrogenic activity & Bioassay used & Reference \\
\hline Japan & Sewage treatment effluents & $5-15 \mathrm{ng} / \ell$ & YES & Matsui et al., 2000 \\
& & & & \\
\hline & Lake water & $1 \mathrm{ng} / \ell$ & YES & Matsui et al., 2000 \\
\hline Korea & River water & $0.5 \mathrm{pg} / \ell-7.4 \mathrm{ng} / \ell$ & E-screen & Oh et al., 2000 \\
\hline Korea & River water & $0.005-1.92 \mathrm{ng} / \ell$ & E-screen & Oh et al., 2006 \\
\hline China, Lake Taihu & Lake water & $4.8-12.1 \mathrm{ng} / \ell$ & MVLN & Shen et al., 2001 \\
\hline China, Lake Taihu & Lake water & $2.2-8.3 \mathrm{ng} / \ell$ & HGELN* & Shen et al., 2001 \\
\hline Belgium & Rivers & $10 \mathrm{ng} / \ell$ & YES & Witters et al., 2001 \\
\hline United Kingdom & Streams & $0-26.5 \mathrm{ng} / \ell$ & YES & Matthiessen et al., 2006 \\
\hline South Africa & Surface, ground and river water & $0.31-2.1 \mathrm{ng} / \ell$ & YES & Aneck-Hahn et al., 2008 \\
\hline South Africa & Small industry effluents & $0.001-5.8 \mathrm{ng} / \ell$ & YES & Mahomed et al., 2008 \\
\hline South Africa & Surface, ground and river water & $0.16-1.92 \mathrm{ng} / \ell$ & YES & Bornman et al., 2007 \\
\hline South Africa & Surface, ground and river water & $0.32-16.0 \mathrm{ng} / \ell$ & ER-Calux $®$ & Bornman et al., 2007 \\
\hline
\end{tabular}

water could be due to contamination as a result of infiltration of domestic effluents and raw sewage. It is unlikely that agricultural runoff would contribute much, as there is very little farming activity in the region, other than a small amount of subsistence farming.

Published information on fish studies (Metcalfe et al., 2001; Seki et al., 2005; Young et al., 2002) shows that exposure to average long-term EEq concentrations in excess of $1 \mathrm{ng} / \ell$, if bioavailable, are likely to cause ovotestis and other oestrogen-induced intersexual abnormalities (e.g. Vitellogenin induction) in some fish (Matthiessen et al., 2006). This has also been observed in South Africa in Rietvlei Nature Reserve (Barnhoorn et al., 2004; Bornman et al., 2007). Van Wyk et al. (2005) found that exposing male Oreochromas mossambicus to estrogen for $3 \mathrm{~d}$ caused plasma vitellogenin (Vtg) to increase. Using the in vitro Xenopus laevis liver culture Vtg bioassay estrogenic activity was detected in different types of water in the Western Cape and Windhoek, Namibia (Van Wyk et al., 2005).

Measuring human exposure to EDCs (e.g., alkylphenols, phthalate esters and bisphenol-A) is difficult because the data are still sparse. There is, however, considerable concern because these compounds are so ubiquitous in the modern environment. Not only were some nonylphenol ethoxylates found in water in New Jersey, USA (Toppari et al., 1996), but more importantly also in South African drinking water $(<0.005$ to $0.05 \mathrm{mg} / \ell$; EEqs: $10^{-9}-10^{-8} \mathrm{M}$ ) (De Jager et al., 2002).

Other rural communities in South Africa may already suffer from health effects caused by exposure to chemicals like DDT, used for malaria vector control (Aneck-Hahn et al., 2007). Water is a potential source for human exposure to EDCs, although it is probably not a major exposure pathway. In developing countries, where drinking water is not generally treated it may be contaminated with industrial and naturally occurring chemicals. It must therefore be taken into account that the community might be exposed to EDCs through diet (in these communities a relatively high soybean intake), the environment (air and water pollution), domestic products (household cleaning products) and occupation. The routes of exposure of the poverty-stricken rural communities will be similar, as even the drinking water was found to be oestrogenic. In fact these communities seem to be at higher risk due to the fact that they lack proper water services in the area. Together with other sources of exposure, the potential for health risks needs further investigation.

\section{Conclusion}

To our knowledge, and despite the limitations of the study, this is the first report on oestrogenic potential in drinking water in the Limpopo Province, South Africa. The origin and identity of the oestrogenic compounds are as yet unknown. It may well be argued that EDC exposure may at least in part contribute to the high incidence of stunted growth in the study population. These preliminary findings indicate a need for further study of these water sources to identify the chemicals responsible for the contamination of and oestrogenic activity in drinking water.

\section{Acknowledgements}

The authors wish to acknowledge Professor J Sumpter, Department of Biological Sciences, Brunel University, Uxbridge, London, for the generous donation of the yeast stock culture (Saccharomyces cerevisiae) for the Recombinant Yeast Oestrogen Bioassay (RCBA); Prof. F Comhaire, head of the WHO collaborating Andrology Unit, University Hospital Gent and, founder and spokesman EMR Gent for their technical assistance; the National Research Foundation (NRF) for funding the project; and Dr IEJ Barnhoorn for her invaluable assistance in the laboratory.

\section{References}

ANECK-HAHN NH (2003) Screening for Anti-Oxidant Pollutants and Estrogenicity in Drinking Water in Poverty Stricken Areas of South Africa. Doctorate Technologiae, Technikon Pretoria, Pretoria.

ANECK-HAHN NH, BORNMAN MS and DE JAGER C (2008) Preliminary assessment of oestrogenic activity in water sources in Rietvlei Nature Reserve, Gauteng, South Africa. Afr. J. Aquat. Sci. 33 (3) 249-254.

ANECK-HAHN NH, DE JAGER C, BORNMAN MS and DU TOIT D (2005) Oestrogenic activity using a recombinant yeast screen assay (RCBA) in South African laboratory water sources. Water SA 31 (2) 253-256. http://www.wrc.org.za/downloads/watersa/2005/Apr05/1784.pdf

ANECK-HAHN NH, SCHULENBURG GW, BORNMAN MS, FARIAS P and DE JAGER C (2007) Impaired semen quality associated with environmental DDT exposure in young men living in a malaria area in the Limpopo Province, South Africa. J. Androl. 28 (3) $423-434$.

BARNHOORN IEJ, BORNMAN MS, PIETERSE GM and VAN VUUREN JHJ (2004) Histological evidence of intersex in feral 
sharptooth catfish (Clarias gariepinus) from an estrogen-polluted water source in Gauteng South Africa. Environ. Toxicol. 19603 608.

BERESFORD N (1999) Personal communication. Department of Biological Sciences, Brunel University, Uxbridge, United Kingdom.

BORNMAN MS, VAN VUREN JH, BOUWMAN H, DE JAGER C, GENTHE B and BARNHOORN EJ (2007) The Use of Sentinel Species to Determine the Endocrine Disruptive Activity in an Urban Nature Reserve. WRC Report No 1505/1/07. Water Research Commission, Pretoria, South Africa.

COLBORN T, VOMSAAL FS and SOTO A (1993) Developmental effects of endocrine-disrupting chemicals in wildlife and humans. Environ Health Perspect. 101 (5) 378-384.

DAMSTRA T, BARLOW S, BERGMAN A, KAVLOCK R, VAN DER KRAAK G (2002) Global Assessment of the State-of-Science of Endocrine Disruptors. WHO/PCS/EDC/02.2. 180 pp. http://www. who.int/ipcs/publications/new_issues/endocrine_disruptors/en/.

DARBRE PD (2006) Metalloestrogens: an emerging class of inorganic xenoestrogens with potential to add to the oestrogenic burden of the human breast. J. Appl. Toxicol. 26 191-197.

DE JAGER C, BORNMAN MS, ANECK-HAHN N, FOURIE MH and BAILEY JL (2001) Additive effects of p-nonylphenol and phytoestrogens on reproductive parameters in male rats. Poster Presentation, Proc. $2^{\text {nd }}$ nt. Conf. Male Mediated Development Toxicity. 20-23 June, Montreal, Canada.

DE JAGER C, MYBURG J, VAN DER BURG B, LEMMEN F and BORNMAN MS (2000) Hormones and endocrine disrupters in food and water: Possible Impact on Human Health. RH Workshop, Rigshospitalet, Copenhagen University Hospital, 27-30 May. 73-74.

DE JAGER C, MYBURGH J, VAN DER BURG B, LEMMEN JG and BORNMAN MS (2002) Estrogenic contamination of South African river waters: A pilot study. American Waterworks Water Association, April 18-20, 2002, Cincinnati, Ohio, USA.

DESBROW C, ROUTLEDGE EJ, BRIGHTY GC, SUMPTER JP and WALDOCK M (1998) Identification of estrogenic chemicals in STW effluent. 1. Chemical fractionation and in vitro biological screening. Environ. Sci. Technol. 32 1549-1558.

ESKENAZI B, MARKS AR, BRADMAN A, FENSTER L, CAROLINE J, BARR D and JEWELL NP (2006) In-utero exposure to dichlorodiphenyltrichloroethane (DDT) and dichlorodiphenyldichloroethylene (DDE) and neurodevelopment among young Mexican American children. Pediatrics 118 (1) 233-241.

GUILLETTE LJ (Jr) (2006) Endocrine disrupting contaminants beyond the dogma. Environ. Health Perspect. 114 (1) 9-12.

JACKSON A, DAVIS J, PITHER RJ, RODGER A, HANNON MJ (2001) Estrogen derived steroidal metal complexes: agents for cellular delivery of metal centers to estrogen receptor-positive cells. Inorg. Chem. 40 3964-3973.

JOBLING S and TYLER CR (2006) Introduction: The ecological relevance of chemically induced endocrine disruption in wildlife. Environ. Health Perspect. 114 (suppl 1) 7-8.

KAMRIN MA (1996) The mismeasure of risk: a review of 'Our Stolen Future'. Scientific American: Reviews and Commentaries. 1-4. Accessed on 20 October 2007. http://www.sciam. com/0996issue/0996review2.htm

KILIAN E, DELPORT R, BORNMAN MS and DE JAGER C (2007) Simultaneous exposure to low concentrations of dichlorodiphenyltrichloroethane, deltamethrin, nonylphenol and phytoestrogens has negative effects on the reproductive parameters in male SpraqueDawley rats. Andrologia 39 128-135.

KIRKHORN SR and SCHENKER MB (2002) Current health effects of agricultural work: Respiratory disease, cancer, reproductive effects, musculoskeletal injuries and pesticide-related illnesses. J. Agric. Saf. Health 8 199-214.

KRISHNAN AV, STATHIS P, PERMUTH SF, TOKES L and FELDMAN D (1993) Bisphenol-A: An estrogenic substance is released from polycarbonate flasks during autoclaving. Endocrinol. 132 2279-2286

LEGLER J, VAN DEN BRINK CE, BROUWER A, MURK AJ, VAN DER SAAG PT, VETHAAK AD and VAN DER BURG B (1999) Development of a stably transfected estrogen receptor-mediated luciferase reporter gene assay in the human T47D breast cancer cell line. Toxicol. Sci. 48 55-66.

MATSUI S, TAKIGAMI H, MATSUDA T, TANIGUCHI N, ADACHI J, KAWAMI H and SHIMIZU Y (2000) Estrogen and estrogen mimics contamination in water and the role of sewage treatment. Water Sci. Technol. 42 (12) 173-179.

MATTIESSEN P, ARNOLD D, JOHNSON AC, PEPPER TJ, POTTINGER TG and PULMAN KGT (2006) Contamination of headwater streams in the United Kingdom by oestrogenic hormones from livestock farms. Sci Tot. Environ. 367 616-630.

MEINTJIES CJ, ROUSSEAU BG and VILJOEN DJ (1995) Gauteng: Statistical macroeconomic review, Development Bank of Southern Africa. Development Information Paper 1064.

METCALFE CD, METCALFE TL, KIPARISSIS Y, KOENIG BG, KHAN C, HUGHES RJ, CROLEY TR, MARCH R and POTTER $\mathrm{T}$ (2001) Estrogenic potency of chemicals detected in sewage treatment plant effluents as determined by in vivo assays with Japanese medaka (Orysias latipes). Environ. Toxicol. Chem. 20 297-308.

MAHOMED SI, VOYI KVV, ANECK-HAHN NH and DE JAGER C (2008) Oestrogenicity and chemical target analysis of water from small-sized industries in Pretoria, South Africa. Water SA 34 (3) 357-363. http://www.wrc.org.za/downloads/watersa/2008/July/1952. pd

OH S-M, PARK K and CHUNG K-H (2006) Combination of in vitro bioassays encompassing different mechanisms to determine the endocrine-disrupting effects of river water. Sci. Total Environ. 354 252-264.

OH S-M, CHOUNG S-Y, SHEEN Y-Y and CHUNG K-H (2000) Quantitative assessment of estrogenic activity in the water environment of Korea by the e-screen assay. Sci. Total Environ. 263 161-169.

PALANZA P, GIOIOSA L, VOM SAAL FS and PARMAGIANI S (2008) Effects of developmental exposure to bisphenol A on brain and behaviour in mice. Environ. Res. 108 150-157.

PHILLIPS KP and FOSTER WG (2008) Key developments in endocrine disrupter research and human health. J. Toxicol. Environ. Health B 11 322-344.

PHILLIPS B and HARRISON P (1999) Overview of the endocrine disrupters issue. In: Hester RE andHarrison RM (eds.) Issues in Environmental Science and Technology. No.12: Endocrine Disrupting Chemicals. The Royal Society of Chemistry, Cambridge. 1-26.

PONS M, GAGNE D, NICOLAS JC and MEHTALI R (1990) A new cellular model of response to estrogens: a bioluminescent test to characterize (anti)estrogen molecules. Biotechnol. 9 450-459.

ROUTLEDGE EJ and SUMPTER JP (1996) Estrogenic activity of surfactants and some of their degradation products assessed using a recombinant yeast screen. Environ. Toxicol. Chem. 15 (3) 241-248.

ROUTLEDGE EJ, SHEAHAN D, DESBROW C, BRIGHTY GC, WALDOCK M and SUMPTER JP (1998) Identification of estrogenic chemicals in STW effluent. 2. In vivo responses in trout and roach. Environ. Sci. Technol. 32 (11) 1559-1565.

SAFE SH and GAIDO K (1998) Phytoestrogens and anthropogenic estrogenic compounds. Environ. Toxicol. Chem. 17 119-126.

SARMAH AK, NORTHCOTT GL, LEUSCH FDL and TREMBLAY LA (2006) A survey of endocrine disrupting chemicals (EDCs) in municipal sewage and animal waste effluents in the Waikato region of New Zealand. Sci. Total Environ. 355 135-144.

SEKI AM, YOKOTA H, MAEDA M and KOBOYASHI K (2005) Fish full life-cycle testing for $17 \beta$-estradiol on medaka (Oryzias latipes). Environ. Toxicol. Chem. 24 1259-1266.

SHARPE R and SKAKKEBEAK NE (1993) Are oestrogens involved in falling sperm counts and disorders of the male reproductive tract? The Lancet $\mathbf{3 4 1}$ 1392-1395

SHEN JH, GUTENDORF B, VAHL HH, SHEN L and WESTENDORF $\mathrm{J}$ (2001) Toxicological profile of pollutants in surface water from an area in Taihu Lake, Yangtze Delta. Toxicol. 166 71-78.

SOTO AM, SONNESCHEIN C, CHUNG KL, FERNANDEZ MF, OLEA N and SERRANO FO (1995) The E-screen assay as a tool to identify estrogens - an update on estrogenic environmental pollutants. Environ. Health Perspect. 103 (Suppl. 7) 113-122.

THERON M (2000) Inadequate Dietary Intake as the Cause of Stunting amongst Children Aged 12 to 24 Months Living in an Informal 
Settlement in Gauteng. M. Technology Thesis, Dept Food and Nutrition, Technikon Pretoria.

THERON M, AMISSAH A, KLEYNHANS IC, ALBERTSE E and MACINTYRE UE (2007) Inadequate dietary intake is not the cause of stunting amongst young children living in an informal settlement in Gauteng and rural Limpopo Province in South Africa: the NutriGro study. Pub. Health Nutr. 10 (4) 379-389.

TOPPARI J, LARSEN JC, CHRISTIANSEN P, GIWERCMAN A, GRANDJEAN P, GUILLETTE LJ JR, JÉGOU B, JENSEN TK, JOUNNET P, KEIDING N, LEFFERS H, MCLACHLAN JA, MEYER O, MÜLLER J, RAJPERT-DE MEYTS E, SCHEIKE T, SHARPE R, SUMPTER J and SKAKKEBAEK NE (1996) Male reproductive health and environmental xenoestrogens. Environ. Health Perspect. 104 (Suppl. 4) 741-803.

VAN DEN BELT K, BERCKMANS P, VANGENECHTEN C, VERHEYEN R and WITTERS H (2004) Comparative study on the in vitro/in vivo estrogenic potencies of $17 \beta$-estradiol, estrone, $17 \alpha-$ ethynylestradiol and nonylphenol. Aquat. Toxicol. 66 183-195.
VAN WYK JH, POOL EJ, HURTER E and LESLIE AJ (2005) The Development and Validation of Bioassays to Detect Estrogenic and Anti-androgenic Activity Using Selected Wildlife Species. WRC Report No 926 \& 1253/1/05. Water Research Commission, Pretoria, South Africa.

WITTERS H, VANGENECHTEN C and BERCKMANS P (2001) Detection of estrogenic activity in Flemish surface waters using a in vitro recombinant assay with yeast cells. Water Sci. Technol. 43 117-123.

WORLD HEALTH ORGANIZATION (WHO) (2002) International Programme on Chemical Safety: Global Assessment of the State-ofthe-Science of Endocrine Disruptors, WHO, Geneva.

YOUNG WF, WHITEHOUSE P, JOHNSON I and SOROKIN N (2002) Proposed predicted no effect concentrations (PNECs) for natural and synthetic steroid oestrogens in surface waters. Environment Agency R \& D Technical Report P2-T04/1, England and Wales Environment Agency, Bristol. 172 pp.

ZHANG H, CHANG C-H, LÜA F, LEE D-J, HEA P-J, SHAOA LM and SUC A (2009) Estrogenic activity of fractionate landfill leachate. Sci. Total Environ. 407 879-886. 
